\title{
The trade policy effect in international trade: case of Pakistan
}

\author{
Alassane D. Yeo ${ }^{1,2^{*}}$ (D) and Aimin Deng ${ }^{1,2}$
}

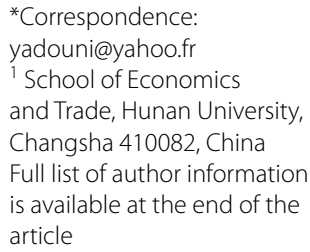

\begin{abstract}
The debate on free trade and protectionism is ravaging in recent years. The industrialized countries are losing more and more market to the benefit of emerging countries. Liberals worry about new tariff barriers, while protectionists fear that unevenly distributed losses and gains will lead to significant economic dislocation of workers in import-competing industries. The economic policy of restricting imports and the economic policy of opening exports remain two critical measures of international trade. This study uses the gravity model to investigate the impacts of trade policy measures on trade flows between Pakistan and its dominant trading pattern for the period 2006 to 2015. The findings revealed the statistically significant correlation of trade policy variables on exports and imports. The study extended the analysis by examining four specificities groups of trade policy and continuing the analysis by estimating different country groups according to geographical or organizational clusters. The findings indicated that the specificities of trade policy have a statistically significant effect on exports and imports. Moreover, the signs of the coefficients are opposite in both models. The main political implication is that the proliferation of free trade agreements can have a positive impact on international trade.
\end{abstract}

Keywords: Free trade, Protectionism, Trade policy, Gravity model

\section{Introduction}

Although more and more countries adopt the idea of free trade, protectionism has rebounded in the wake of the economic crisis of 1929 and remains a reality of our days. The principle of "learning by doing", national security or unfair competition has also been proposed over time to justify the use of protectionism. Liberalization (free trade policy) and protectionism are two fundamental instruments for governments to control international trade, in other words, two different types of foreign trade policy. Free trade policy is the minimum of state intervention in foreign trade, developed by free-market forces of supply and demand, while protectionism provides for the protection of the internal market from the international competition through the use of tariff and non-tariff instruments. Protectionism according to Nicita et al. (2013) refers to the measurement taken by the government to promote the local industry in the face of international competition. Baldwin (1970) defines as any measure (public or private) that causes internationally traded goods and services, or devoted to the

C The Author(s) 2019. This article is distributed under the terms of the Creative Commons Attribution 4.0 International License (http:/ creativecommons.org/licenses/by/4.0/), which permits unrestricted use, distribution, and reproduction in any medium, provided you give appropriate credit to the original author(s) and the source, provide a link to the Creative Commons license, and indicate if changes were made. 
production of these goods and services to be allocated, in such a way as to reduce potential real-world income. These two categories of trade policies are specific to each country and reflect the extent of government intervention in international trade, while under the policy of liberalization, the market is an essential regulator of foreign trade, protectionism practically excludes the free functioning of market forces.

Many researchers have tempted to examine the impact of these policies on international trade. Campi and Dueñas (2019) analyze the effect of trade agreements (TAs) with and without IPRs on bilateral trade flows. Levitt et al. (2018) examine the impact of China's trade liberalization on the greenhouse gas emissions of WTO countries. Others researchers have focused on the case of Pakistan. Lewis and Guisinger (1968) deals with the Effects of Trade Policy on Domestic Relative Prices in Pakistan. Baysan (1992) describes the trade policies in Pakistan.

Recently, Pakistan's growth continues to accelerate, but macroeconomic imbalances are widening. Macroeconomic stability is a significant concern for the near-term economic outlook. According to the World Bank database, Pakistan's GDP growth increased by $0.8 \%$ points over the previous year to reach $5.3 \%$ in FY17.

In 2016, Pakistan exported $\$ 24.2$ billion and imported $\$ 48.1$ billion, leading to a negative trade balance of $\$ 23.9$ billion. Also, Pakistan's GDP was $\$ 278$ billion, and it per capita GDP was $\$ 5.24 \mathrm{k}$. During the last 10 years, the exports of Pakistan have decreased at an annualized rate of $-4.1 \%$, from $\$ 29.1 \mathrm{~B}$ in 2011 to $\$ 24.2 \mathrm{~B}$ in 2016 and the imports of Pakistan have increased at an annualized rate of $1.3 \%$ from $\$ 44.6 \mathrm{~B}$ in 2011 to $\$ 48.1 \mathrm{~B}$ in 2016. Pakistan's trade balance was negative by $\$ 23.9$ billion in net imports in 2016, while in 1995, the country's trade balance was still negative by $\$ 664$ million (Fig. 1). In 2017, the main export destinations of Pakistan are the United Kingdom (\$1.63B), China (\$1.50B), Germany (\$1.28B) and Spain (\$0.9B), and main origins are China (\$16.89B), the United Arab Emirates (\$8.39B) the United States (\$6.40B), Saudi Arabia (\$3.06B) and Japan (\$2.51B) (Table 1).

To understand the origin of the negative balance and improve trade in Pakistan in the next 10 years, we will look at the impact of the trade policy such as non-tariff barriers, environmental policy stringency, entry cost and free trade agreement on trade between Pakistan and its key partners.

The rest of this paper is structured as follows: Sect. 2 provides a revision of the relevant literature with recommendations for the approach adopted here. Section 3

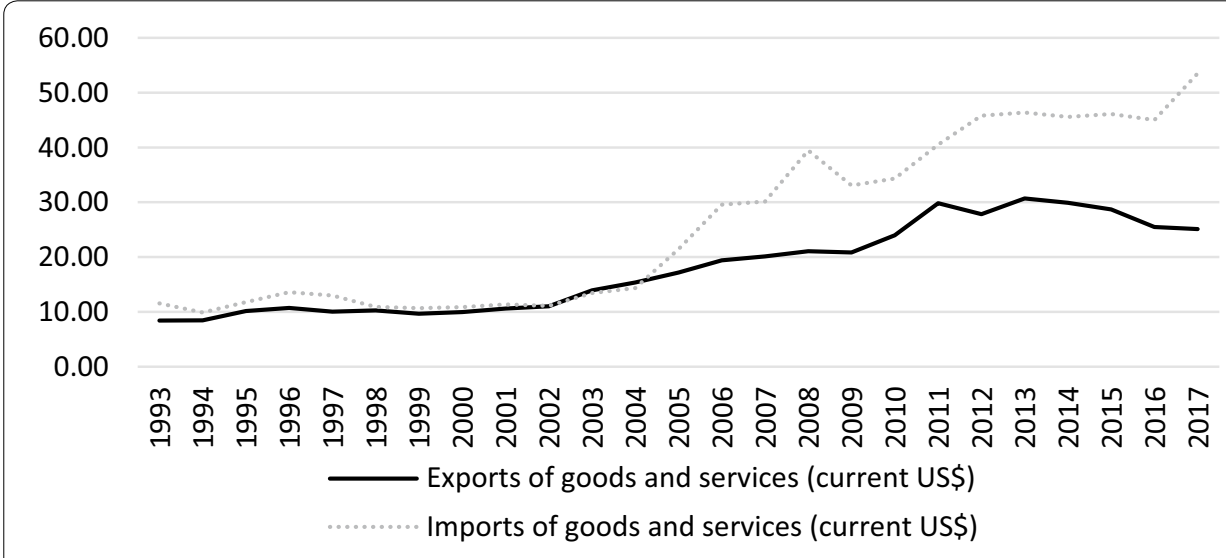

Fig. 1 Pakistan's trade flow (source: World Bank data) 
Table 1 Pakistan major export and import markets (US\$ billion) Source: World Bank data

\begin{tabular}{lllllllll}
\hline Rank & Exports to & $\mathbf{2 0 1 5}$ & $\mathbf{2 0 1 6}$ & $\mathbf{2 0 1 7}$ & $\begin{array}{l}\text { Imports } \\
\text { from }\end{array}$ & $\mathbf{2 0 1 5}$ & $\mathbf{2 0 1 6}$ & $\mathbf{2 0 1 7}$ \\
\hline 1 & USA & 3.66 & 3.43 & 3.56 & China & 13 & 15.3 & 16.9 \\
2 & UK & 1.57 & 1.56 & 1.63 & UAE & 6.63 & 6.99 & 8.39 \\
3 & China & 1.93 & 1.59 & 1.51 & USA & 5.58 & 5.44 & 6.4 \\
4 & Germany & 1.15 & 1.19 & 1.29 & Saudi & 3.44 & 2.22 & 3.06 \\
& Spain & 0.79 & 0.84 & 0.91 & Japan & 1.91 & 2.13 & 2.51 \\
5 & UAE & 0.9 & 0.79 & 0.87 & UK & 2.18 & 2.18 & 2.41 \\
6 & Nether- & 0.67 & 0.62 & 0.76 & Germany & 2.12 & 2.18 & 2.4 \\
7 & lands & & & & & & & \\
& Italy & 0.62 & 0.67 & 0.7 & India & 1.98 & 1.99 & 2.03 \\
8 & Belgium & 0.6 & 0.66 & 0.7 & Nether- & 1.03 & 1.04 & 1.7 \\
9 & Korea & 0.3 & 0.26 & 0.47 & Korea & 0.97 & 0.99 & 1.34 \\
\hline
\end{tabular}

describes the data and methodology. Section 4 presents and discusses the results, while Sect. 5 concludes and provides some policy implications.

\section{Literature review}

The relevant literature reviews of this study discussed the impact of non-tariff barriers (Carrère and De Melo 2011), environmental policy stringency (van Beers and van den Bergh 1997), entry cost (Lincoln and McCallum 2016) and free trade agreement (Klimenko et al. 2008) on trade flows.

Referring to non-tariff barriers (NTBs), Carrère and De Melo (2011) offer an alternative approach for estimating the effects of non-tariff measures (NTMs) on trade flows. Ghodsi and Stehrer (2016) analyze the impact of trade policy instruments in the global economy, applying a four-stage approach in order to assess the effect of trade policy measures on the average annual growth of labor productivity. Several works of literature present NTMs as trade policy instruments (Van Tongeren et al. 2009; Beghin et al. 2015). Usually, the gravity model is used to estimate the effect of NTMs on trade (Kee et al. 2009; Disdier and Marette 2010). Khouilid and Echaoui (2017) used the elasticity of imported demand and an estimated gravitational equation for a sample of 28 countries of different levels of development to analyze the impact of non-tariff measures on Moroccan exportation. Genç and Law (2014) highlight the growing importance of nonpolicy-induced barriers to trade. Lee and Swagel (1997) use data of trade flows, production and trade barriers for 41 countries in 1988 to examine the political and economic determinants of non-tariff barriers as well as the impact of protection (both tariff and non-tariff) on trade flow. Deardorff and Stern (1997) assess currently available methods for quantifying NTBs, notably frequency type measures, price comparison measures, quantity impact measures and measures of equivalent nominal rates of assistance.

Many researchers investigate the environmental policy stringency impacts on trade (Grossman and Krueger 1993b). Lan et al. (2017) provided an examination of the linkage between environmental regulation stringency and the demand for goods and services and found that higher charges lead to a reduction in supply for established firms. Walter (1973) looks into the pollution content of US trade using input-output analysis. Their 
results are significant and show that the pollution content of US exports is found to be $1.75 \%$ of total exports while the pollution content of US imports is found to be $1.52 \%$ of total imports. In contrast, Kozluk and Timiliotis (2016) find that environmental policies are not a significant driver of international trade patterns. Van Beers and van den Bergh (1997) apply a gravity model to examine the impact of relatively strict environmental regulations on a country's exports and imports. In the case of trade flows of pollutionintensive goods used as an independent variable. However, he found no effect of a relatively stringent environmental policy on exports of pollution-intensive goods.

The analysis also contributes to the international trade literature analyzing the empirical relationship between entry cost and international trade; see Arkolakis (2010) and Hummels and Klenow (2005). The cost of entry of goods and services significantly impacts trade flows. A high cost of entry of products and services can substantially reduce trade. Lincoln and McCallum (2016) use confidential microdata from the US Census and show that export rose from $21 \%$ in 1987 to 39\% in 2006 have been caused by declining costs of entering foreign markets. There is evidence that entry costs have dropped significantly in the United States during this period. Trade policies encouraging product entry, such as advertising products in destination markets through export promotion agencies, would result in more firm entry and generate higher export revenues (Steingress 2015).

More recently, with the opening of the economy, free trade agreements have been multiplied (Kawai, and Urata 2012; Bergsten 1996). For Grossman and Helpman (1993a), free trade agreements (FTA) are relevant trade policies, especially for the least developed countries. Urata and Kiyota (2003) demonstrated the positive impact of an East Asia FTA on the GDP and welfare of member countries. Rotunno (2016) found that countries are more likely to sign FTAs after the unexpected exit of their leaders when political instability is high. Shujiro and Misa (2007) used the estimation of a gravity equation to discern the impacts of FTAs on bilateral trade flows, i.e., trade creation and diversion effects. The results of this analysis revealed that FTAs bring about trade creation effect and trade diversion effect is limited. Based on a well-known GTAP model, Qi and Zhang's (2018) study attempts to assess the economic impact of the ChAFTA not only on the Australasian and the Chinese economies, but also on the rest of the world. The results show that China and Australia could benefit significantly regarding raising the growth rates of their GDP, exports, factor prices, and economic welfare through either a full or even partial implementation of ChAFTA. In contrast, the rest of the world may suffer from such ChAFTA as there will be some trade diversion effect.

\section{Methodology}

\subsection{Conceptual framework}

Established for the first time by Tinbergen (1962), followed by Pulliainen (1963) and Pöyhönen (1963), and then by Linnemann (1966), the gravity model is known in its traditional form of predicting bilateral trade flow based on the economics sizes, often using GDP measurements and the distance between two units. According to Bergstrand (1985), typically, the log-linear equation specifies that flow from origin $i$ to destination $j$ can be explained by the economic forces at the trade flow origin, economic forces at the flow destination, and the economic forces either aiding or resisting the flow movement from origin to the destination. The approach uses a gravitational model based on bilateral trade flows. For this analysis, it is specified as follows: 
$\ln Y_{i j, t}=\alpha X_{i j, t}+\beta$ trade policy $\mathrm{ij}_{\mathrm{j}, \mathrm{t}}+\varepsilon_{\mathrm{ij}, \mathrm{t}}$,

where $Y$ is total trade, matrix $X$ includes a set of control variables, and $\varepsilon$ is the error term. Variable $Y$ includes:

$\mathrm{EX}_{i j}=$ exports of goods and services of country $i$ to country $j$ in thousands of US $\$$ and $\mathrm{IMij}=$ imports of goods and services of country $i$ to country $j$ in thousands of US $\$$.

The control variables in matrix $X$ are:

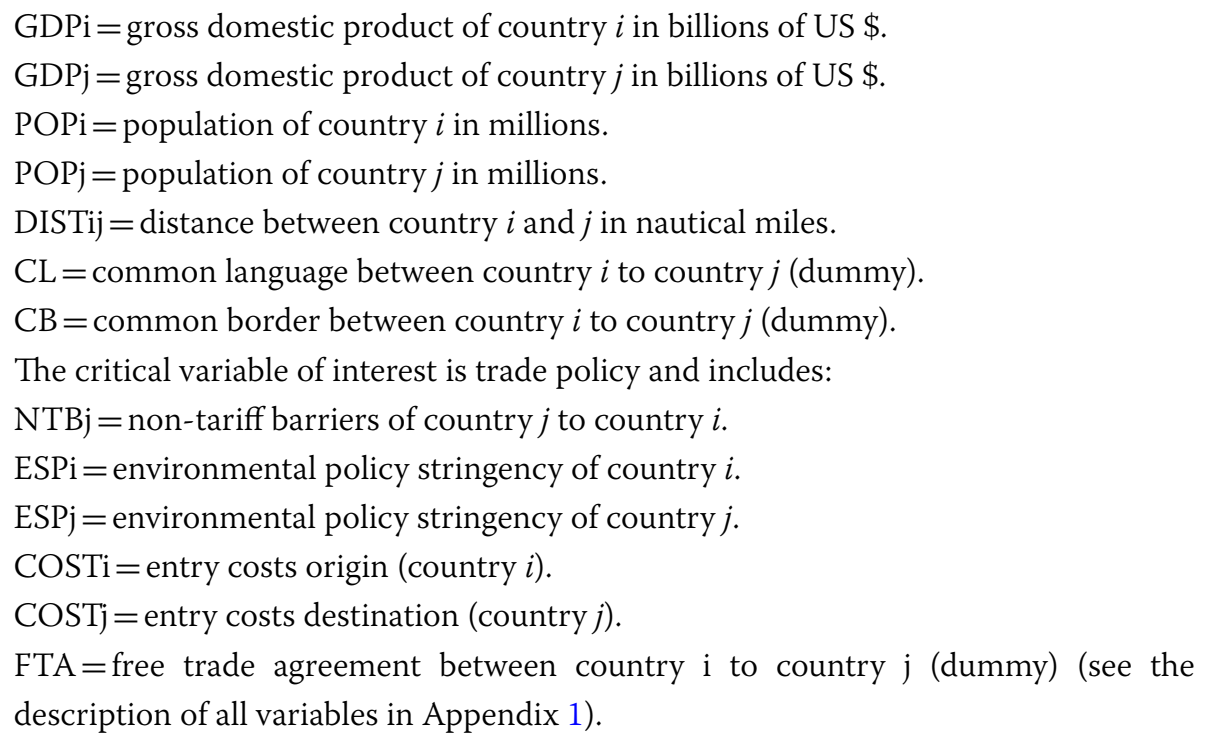

The first critical variable used in the analysis is environmental policy stringency denoted as EPS ${ }_{i}$ and $E S_{j}$, which represent a country-specific and internationally comparable measure of the stringency of environmental policy. Stringency defined as the degree to which environmental policies put an explicit or implicit price on polluting or environmentally harmful behavior (OECD 2017).

The second critical variable is $\mathrm{NTBj}$, which represents tariff imposed by the importing country and aims to restrict imports and exports of goods and services through mechanisms other than simple imposition in order to protect and develop the local industry. NTB is considered to be another EPS and is assumed to have the same effects on trade. The impact of NTB on trade flows is an essential and significant potentially larger barrier to trade than other restriction measures. An increase in NTBs could reduce trade due to the raising of the price of imported goods relative to domestic products. According to the World Trade Organization, non-tariff barriers to trade include import licensing, rules for valuation of goods at customs, pre-shipment inspections, rules of origin ('made in'), and trade prepared investment measures.

Entry cost is included as a critical variable as it can significantly determine the volume of trade flows between countries. Lincoln and McCallum (2016) has analyzed the relationships between entry costs and increasing trade. The declining prices of entering foreign markets cause the rising of export from $21 \%$ in 1987 to $39 \%$ in 2008. 
We dedicate FTA as the fourth critical variable as it appears as an alternative to measures of trade restrictions and therefore has a positive impact on both export and import. The trade agreement is considered as one of the best ways to open foreign markets and reduce barriers between countries. Liberalization, trade facilitation, and improvement FTA are more important measures to facilitate trade between members other than tariff elimination (Okabe 2015). However, free trade agreement regulates tariffs and other trade restrictions between two or more countries.

Traditional gravity variables are present in the analysis as control variables. We include GDP as a control variable for its indication of the performance of a country's economy. In bilateral trade flow, the GDP of the exporting country plays an essential role in trade flows, but with a lower proportion than that of the importing country. The population also has an impact on bilateral trade flows. A large population is a significant consumer market, an abundant labor force and therefore low-cost production, which leads to an increase in trade flows. The impact of the population on bilateral trade flow is positive for exporting countries, while negative for the importing countries. In the gravity model, distance is crucial in the flow of trade between two or more countries. The countries prefer to trade with their nearest neighbors than with the distant lands, because of the high transport cost and other determinants of prices of goods.

Additional dummy variables are the common language and the common border. They seem to have a significant positive effect on bilateral trade flow. A common (official or spoken) language increases trade flows directly by 44\% (Egger and Lassmann 2012). In general, the common language and the common border are measured binary according to whether or not the two countries speak the same language and share the same border. Recently OECD meeting has reported that countries with a common border tend to trade about a third more with each other countries without.

\subsection{Sampling and data collection}

The sample includes 15 countries and Pakistan: United States; United Kingdom; China; Afghanistan; Germany; Spain; United Arab Emirates; Netherlands; Italy; Belgium; Bangladesh; South Korea; France; India; Saudi Arabia. These countries are chosen because they represent nearly three-quarters (70\%) of Pakistani exports in 2017 and represent countries that imported the most Pakistani shipments by dollar value during 2017. All data are collected from the period 2016 to 2015.

The sources of bilateral trade flow data (exports and imports) are the World Integrated Trade Solution (WTIS) and these indicators measure trade flows between Pakistan and importing countries in US dollars. Data on GDP and population are obtained from World Bank data. GDP is in US\$ billion while the population is expressed in millions. Variables related to bilateral distance, common language, the common border from the CEPII GeoDist database. FTA is collected from the WTO website. Distance is measured in kilometers. FTA, CL, CB are dummy variables and take the following values: $0=$ non-free trade agreement/non-common language/non-common border; 1 =free trade agreement/common language/common border.

EPS and NTB are, respectively, environmental policy stringency and non-tariff barriers and come from, respectively, OECD and WTS. Due to the lack of data of some countries forming our panel, we calculated based on Walter and Ugelow's (1979) Environmental Stringency Index, which measures countries' environmental policy strictness 
and ranks countries from 1 (strict) to 7 (tolerant). The same calculations were done for NTB because of the lack of data on European countries in WITS. Measures of EPS and NTB are re-defined on a scale of $1=$ tolerant to $7=$ strict and presented in Appendix 2.

\section{Estimation results}

\subsection{General regressions results}

In this study, we explored the trade flow between Pakistan's and its main trade partners. Form 1995, Pakistan had a negative trade balance of $\$ 664 \mathrm{M}$ in net imports. In 2017, the main export destinations of Pakistan are the United States (\$3.56B), the United Kingdom $(\$ 1.63 \mathrm{~B})$, China $(\$ 1.50 \mathrm{~B})$, Germany $(\$ 1.28 \mathrm{~B})$ and Spain $(\$ 0.9 \mathrm{~B})$, and main origins are China (\$16.89B), the United Arab Emirates (\$8.39B) the United States (\$6.40B), Saudi Arabia (\$3.06B) and Japan (\$2.51B).

The descriptive statistics presented in Appendix 3 shows the results of the effects of trade policies on exports and imports. For this analysis, NTB, EPS, COST, and FTA are chosen as the most critical variable, and command variables are represented by GDP, POP, DIST, CL, and CB. Table 2 provides our estimation result which examined the

Table 2 The effect of trade policy in overall on trade

\begin{tabular}{|c|c|c|c|}
\hline Variables & Expected effects & Log-linear export model & Log-linear import model \\
\hline InGDPj & $(+)$ & $\begin{array}{l}0.319^{* * *} \\
(0.0508)\end{array}$ & $\begin{array}{l}1.158^{* * *} \\
(0.0803)\end{array}$ \\
\hline InPOPj & $(+)$ & $\begin{array}{l}-0.301^{* * *} \\
(0.0437)\end{array}$ & $\begin{array}{l}0.105 \\
(0.0691)\end{array}$ \\
\hline InGDPi & $(+)$ & $\begin{array}{l}0.976 \\
(0.932)\end{array}$ & $\begin{array}{l}0.0480 \\
(1.473)\end{array}$ \\
\hline InPOPi & $(+)$ & $\begin{array}{l}-1.011 \\
(3.275)\end{array}$ & $\begin{array}{l}-0.844 \\
(5.176)\end{array}$ \\
\hline InDISTij & $(-)$ & $\begin{array}{l}-0.142 \\
(0.127)\end{array}$ & $\begin{array}{l}-3.106^{* * *} \\
(0.201)\end{array}$ \\
\hline InNTBj & $(-)$ & $\begin{array}{l}0.817^{* * *} \\
(0.128)\end{array}$ & $\begin{array}{l}-0.457^{* *} \\
(0.202)\end{array}$ \\
\hline InEPSi & $( \pm)$ & $\begin{array}{l}1.199 \\
(0.980)\end{array}$ & $\begin{array}{l}-0.273 \\
(1.549)\end{array}$ \\
\hline InEPSj & $( \pm)$ & $\begin{array}{l}-1.425^{* * *} \\
(0.173)\end{array}$ & $\begin{array}{l}0.0855 \\
(0.274)\end{array}$ \\
\hline InCOSTi & $( \pm)$ & $\begin{array}{l}0.478 \\
(0.296)\end{array}$ & $\begin{array}{l}-0.0407 \\
(0.468)\end{array}$ \\
\hline InCOSTj & $( \pm)$ & $\begin{array}{l}-0.0692^{*} \\
(0.0363)\end{array}$ & $\begin{array}{l}0.211^{* * *} \\
(0.0574)\end{array}$ \\
\hline FTA & $(+)$ & $\begin{array}{l}-0.205 \\
(0.246)\end{array}$ & $\begin{array}{l}1.719^{* * *} \\
(0.389)\end{array}$ \\
\hline$C B$ & $(+)$ & $\begin{array}{l}1.572^{* * *} \\
(0.204)\end{array}$ & $\begin{array}{l}-2.133^{* * * *} \\
(0.322)\end{array}$ \\
\hline $\mathrm{CL}$ & $(+)$ & $\begin{array}{l}1.216^{* * *} \\
(0.134)\end{array}$ & $\begin{array}{l}0.748^{* * *} \\
(0.212)\end{array}$ \\
\hline Constant & $(+)$ & $\begin{array}{l}3.457 \\
(38.99)\end{array}$ & $\begin{array}{l}21.01 \\
(61.62)\end{array}$ \\
\hline Observations & & 150 & 150 \\
\hline$R$-squared & & 0.786 & 0.824 \\
\hline F test & & 38.39 & 48.97 \\
\hline Root MSE & & 0.36892 & 0.5831 \\
\hline
\end{tabular}

Standard errors in parentheses ${ }^{* * *} p<0.01,{ }^{* *} p<0.05,{ }^{*} p<0.1$ 
policy that can affect trade flow between Pakistan and its partners. The econometric problem has been tested. The data are pooled, Durbin's alternative test and BreuschGodfrey test showed no serial correlation in the residual. The GDP of importing countries has a statistically significant and positive influence on total exports and imports value. While the NTB of importing countries was positive and statistically significant for the export equation, it was negative and statistically significant for the import equation. EPS and COST of importing countries were negative and statistically significant in the export equation. COSTj and FTA were positive and statistically significant in the import equation.

The empirical analysis was conducted to determine whether specific aspects of trade policy were essential to trade. The effects of four of the most critical variables were tested for exports and imports. Tables 3 and 4 report a series of specifications where the level of bilateral trade is regressed against the policy variable. The first two columns report the finding of the basic specification, which includes the main critical variables NTBj and (EPSi and EPSj). In column (3) we added additional variables such as entry cost origin and entry cost destination, which were designed to prove the evidence of the

Table 3 The effect of trade policy specificities on exports

\begin{tabular}{|c|c|c|c|c|}
\hline Variables & (1) & (2) & (3) & (4) \\
\hline InGDPj & $\begin{array}{l}0.119^{* *} \\
(0.0468)\end{array}$ & $\begin{array}{l}0.386^{* * *} \\
(0.0486)\end{array}$ & $\begin{array}{l}0.199 * * * \\
(0.0443)\end{array}$ & $\begin{array}{l}0.172^{* * *} \\
(0.0495)\end{array}$ \\
\hline InPOPj & $\begin{array}{l}-0.0537 \\
(0.0360)\end{array}$ & $\begin{array}{l}-0.319^{* * *} \\
(0.0486)\end{array}$ & $\begin{array}{l}-0.0832^{* *} \\
(0.0379)\end{array}$ & $\begin{array}{l}-0.0887^{* *} \\
(0.0367)\end{array}$ \\
\hline InGDPi & $\begin{array}{l}1.074 \\
(1.040)\end{array}$ & $\begin{array}{l}0.750 \\
(1.045)\end{array}$ & $\begin{array}{l}1.336 \\
(1.154)\end{array}$ & $\begin{array}{l}1.032 \\
(1.088)\end{array}$ \\
\hline IngPOPi & $\begin{array}{l}-1.352 \\
(3.678)\end{array}$ & $\begin{array}{l}-0.602 \\
(3.701)\end{array}$ & $\begin{array}{l}-2.158 \\
(3.983)\end{array}$ & $\begin{array}{l}-1.376 \\
(3.850)\end{array}$ \\
\hline InDISTij & $\begin{array}{l}-0.619^{* * *} \\
(0.130)\end{array}$ & $\begin{array}{l}-0.149 \\
(0.140)\end{array}$ & $\begin{array}{l}-0.621^{* * *} \\
(0.142)\end{array}$ & $\begin{array}{l}-0.608^{* * *} \\
(0.136)\end{array}$ \\
\hline InNTBj & $\begin{array}{l}0.584^{* * *} \\
(0.150)\end{array}$ & & & \\
\hline InEPSi & & $\begin{array}{l}0.359 \\
(0.968)\end{array}$ & & \\
\hline InEPSj & & $\begin{array}{l}-1.200^{* * *} \\
(0.187)\end{array}$ & & \\
\hline InCOSTi & & & $\begin{array}{l}0.267 \\
(0.332)\end{array}$ & \\
\hline InCOSTj & & & $\begin{array}{l}-0.0155 \\
(0.0434)\end{array}$ & \\
\hline FTA & & & & $\begin{array}{l}0.352 \\
(0.290)\end{array}$ \\
\hline$C B$ & $\begin{array}{l}0.914^{* * *} \\
(0.170)\end{array}$ & $\begin{array}{l}1.267^{* * *} \\
(0.172)\end{array}$ & $\begin{array}{l}0.774^{* * *} \\
(0.180)\end{array}$ & $\begin{array}{l}0.618^{* * *} \\
(0.224)\end{array}$ \\
\hline $\mathrm{CL}$ & $\begin{array}{l}1.469^{* * *} \\
(0.122)\end{array}$ & $\begin{array}{l}1.365^{* * *} \\
(0.113)\end{array}$ & $\begin{array}{l}1.421^{* * *} \\
(0.151)\end{array}$ & $\begin{array}{l}1.507^{* * *} \\
(0.136)\end{array}$ \\
\hline Constant & $\begin{array}{l}12.94 \\
(43.36)\end{array}$ & $\begin{array}{l}2.841 \\
(43.84)\end{array}$ & $\begin{array}{l}19.92 \\
(46.40)\end{array}$ & $\begin{array}{l}14.43 \\
(45.41)\end{array}$ \\
\hline Observations & 150 & 150 & 150 & 150 \\
\hline$R$-squared & 0.669 & 0.717 & 0.636 & 0.638 \\
\hline$F$ test & 35.66 & 39.50 & 27.15 & 31.00 \\
\hline Root MSE & 0.45026 & 0.41765 & 0.47419 & 0.47135 \\
\hline
\end{tabular}

Standard errors in parentheses ${ }^{* * *} p<0.01,{ }^{* *} p<0.05,{ }^{*} p<0.1$ 
Table 4 The effect of trade policy specificities on imports

\begin{tabular}{|c|c|c|c|c|}
\hline Variables & (1) & (2) & (3) & (4) \\
\hline $\operatorname{lnGDPj}$ & $\begin{array}{l}1.269^{* * *} \\
(0.0650)\end{array}$ & $\begin{array}{l}1.274^{* * *} \\
(0.0733)\end{array}$ & $\begin{array}{l}1.235^{* * *} \\
(0.0583)\end{array}$ & $\begin{array}{l}1.127^{* * *} \\
(0.0635)\end{array}$ \\
\hline InPOPj & $\begin{array}{l}0.151^{* * *} \\
(0.0499)\end{array}$ & $\begin{array}{l}0.110 \\
(0.0733)\end{array}$ & $\begin{array}{l}0.146^{* * *} \\
(0.0499)\end{array}$ & $\begin{array}{l}0.160^{* * *} \\
(0.0471)\end{array}$ \\
\hline InGDPi & $\begin{array}{l}0.0754 \\
(1.444)\end{array}$ & $\begin{array}{l}0.0908 \\
(1.576)\end{array}$ & $\begin{array}{l}0.0212 \\
(1.519)\end{array}$ & $\begin{array}{l}0.0746 \\
(1.398)\end{array}$ \\
\hline InbPOPi & $\begin{array}{l}-1.713 \\
(5.107)\end{array}$ & $\begin{array}{l}-1.772 \\
(5.580)\end{array}$ & $\begin{array}{l}-0.932 \\
(5.241)\end{array}$ & $\begin{array}{l}-1.814 \\
(4.946)\end{array}$ \\
\hline InDISTij & $\begin{array}{l}-3.256^{* * *} \\
(0.180)\end{array}$ & $\begin{array}{l}-3.147^{* * *} \\
(0.211)\end{array}$ & $\begin{array}{l}-3.164^{* * *} \\
(0.187)\end{array}$ & $\begin{array}{l}-3.268^{* * *} \\
(0.175)\end{array}$ \\
\hline InNTBj & $\begin{array}{l}-0.310 \\
(0.208)\end{array}$ & & & \\
\hline InEPSi & & $\begin{array}{l}-0.0758 \\
(1.460)\end{array}$ & & \\
\hline InEPSj & & $\begin{array}{l}-0.306 \\
(0.282)\end{array}$ & & \\
\hline InCOSTi & & & $\begin{array}{l}-0.0332 \\
(0.437)\end{array}$ & \\
\hline InCOSTj & & & $\begin{array}{l}0.112^{*} \\
(0.0571)\end{array}$ & \\
\hline FTA & & & & $\begin{array}{l}1.276^{* * *} \\
(0.373)\end{array}$ \\
\hline$C B$ & $\begin{array}{l}-1.422^{* * *} \\
(0.236)\end{array}$ & $\begin{array}{l}-1.232^{* * *} \\
(0.259)\end{array}$ & $\begin{array}{l}-1.257^{* * *} \\
(0.236)\end{array}$ & $\begin{array}{l}-1.970^{* * *} \\
(0.287)\end{array}$ \\
\hline $\mathrm{CL}$ & $\begin{array}{l}0.0814 \\
(0.169)\end{array}$ & $\begin{array}{l}0.0698 \\
(0.171)\end{array}$ & $\begin{array}{l}0.296 \\
(0.198)\end{array}$ & $\begin{array}{l}0.298^{*} \\
(0.174)\end{array}$ \\
\hline Constant & $\begin{array}{l}34.17 \\
(60.21)\end{array}$ & $\begin{array}{l}34.60 \\
(66.10)\end{array}$ & $\begin{array}{l}20.45 \\
(61.05)\end{array}$ & $\begin{array}{l}39.52 \\
(58.33)\end{array}$ \\
\hline Observations & 150 & 150 & 150 & 150 \\
\hline$R$-squared & 0.790 & 0.789 & 0.793 & 0.803 \\
\hline F test & 66.38 & 58.06 & 59.43 & 71.96 \\
\hline Root MSE & 0.62521 & 0.6297 & 0.6239 & 0.60545 \\
\hline
\end{tabular}

Standard errors in parentheses ${ }^{* * *} p<0.01,{ }^{* *} p<0.05,{ }^{*} p<0.1$

impact of entry cost and test the sensitivity of the results to the inclusion of additional explanatory variables. The specification (4) reports the result where the level of trade is regressed with control variables adding dummy variables (FTA).

The results in Table 3 revealed a positive and statistically significant effect of specificities (1), (2) on exports. GDP of country $j$ and BC are found to be statistically correlated with exports. The population of importing countries and distance variables were negative and statistically significant in the export model.

Table 4 shows the results of the regression of the effect of trade specificities on imports. In contrast to the export model, columns (3) and (4) show a positive and significant effect of these variables on imports. The sign of COSTj is positive and statistically significant at the $1 \%$ of the level while the sign of FTA is positive and statistically significant at the $10 \%$ of the level. The results in Table 4 of the control variables indicate that GDPj, POPj, DISTij and CB are statistically significant determinants for the import model.

The results presented in Tables 3 and 4 show that the sign of the coefficient of NTB is positive and statistically significant at $10 \%$ of the level for the export model, while 
negative and statistically significant at $5 \%$ of the level for import model. The coefficient of EPSj has an expected negative sign and statistically significant at $10 \%$ of the level for the export model and is not significant for import model, while the coefficient of FTA is positive and significant correlated with import model at $10 \%$ of the level and is not significant for export model. In both models, COSTj is statistically significant, moreover negative at $1 \%$ for the export model and positive at $10 \%$ for the import model.

\subsection{Results for specific countries}

We carried out several robustness checks to verify the validity of the results obtained in the general model when estimating the different groups of countries according to geographical or organizational groups. The results of these checks are robust and reinforce the proposition of the paper. The results of the regression analysis are in line with those of Haveman and Shatz (2004a, b), who found that tariff barriers against the least developed countries have fallen dramatically and are exceptionally low in the EU. For many developing countries, import and export barriers still significantly hamper trade.

\subsubsection{OECD}

It is a forum of countries describing themselves as committed to democracy and the market economy, offering a platform to compare political experiences, seek answers to common problems, and finally identify good practices and coordinate the national and international policies of its members. Most OECD members are high-income economies with a very high Human Development Index (HDI) and are regarded as developed countries. As of 2017, the OECD member states collectively comprised $62.2 \%$ of global nominal GDP (US\$49.6 trillion) and $42.8 \%$ of global GDP (Int $\$ 54.2$ trillion) at purchasing power parity.

The estimate of the correlation of non-tariff barriers with export and import suggests that OECD imports and exports are 1\% higher than the tariffs of other OECD members for import lines at $15 \%$ more AVEs for its imposed NTMs. The estimator is found to be statistically significant, and the high positive coefficient implies that the correlation between tariff and AVE of NTMs is complimentary. An increase of 1\% in OECD partner's NTB will enhance exports and imports value, respectively, by 8.424 and 8.724 . The results show that the NTB imposed by members of the OECD countries affect Pakistan's trade flows positively twice as much as other groups of countries.

\subsubsection{SAFTA}

The South Asian Free Trade Agreement is a free trade association that aims to reduce intra-regional tariffs among the seven members, including Pakistan. These countries exist in the same geographic location and have relatively low environmental policies and barrier rates. The results show the impact of FTA on Pakistan's exports during recent years. Indeed, an increase of 5\% of FTA will increase the export value of 0.614 . The sign of the coefficient of FTA is positive and statistically significant for the export model and is not significant for the import model. We found a similar result with those obtained with OECD countries for the export model. Moreover, in the import model, the results are different; NTB, EPS and COST of importing countries have a negative and statistically significant effect on imports. 


\subsubsection{APEC}

Asia-Pacific Economic Cooperation constituted China, USA, Korea, which are Pakistan's main importers and exporters. APEC has been criticized for promoting free trade agreements that would impose restrictions on national and local laws, which regulate and ensure labor rights, environmental protection and safe and affordable access to medicine. However, instead of being to their advantage, these decisions have a significant negative impact on them (Gerhardt and 2011). The results suggest that all coefficients have the expected signs in the export and import models, except for the EPSj coefficient, for which the result is positive and statistically significant at the $10 \%$ level for both equations. In consequence, the hypothesis that more stringent environmental policies lower total bilateral imports and exports can be rejected.

\subsubsection{GCC}

United Arab Emirates, Saudi Arabia, and Pakistan share the common faith of Islam and Arabian culture. They also share an economic interest, which is to diversify their growing economies away from oil. The results of bilateral export and import between Pakistan and these countries are showing an insignificant effect of all variables for the import model. NTBj was found to be positive and statistically significantly correlated with export and EPSj negatively and statistically significantly at $5 \%$ of the level. In this analysis, we found that high cost and stringent environments reduce partner countries' exports and imports. However, the hypothesis that non-tariff barriers reduce trade flow also is being questioned in the case of trade between Pakistan and countries of the OECD and SAFTA. Furthermore, The FTA does not seem to affect trade in this case.

\section{Conclusions}

This study investigates the influences of trade policy measures on trade flows between Pakistan and its dominant trading pattern for the period 2006 to 2015. The findings revealed the statistically significant correlation of trade policy variables on exports and imports. However, an expected sign of NTBj for the export model and COSTj for the import model have been detected.

The study extended the analysis by examining four specificities groups of trade policy. The finding confirms the precedent analyses with a positive and statistically significant correlation of NTBj with exports and negative correlation of EPSj with imports. While COSTj and FTA were found to be positive and significant for the export model, COSTj and FTA were not significant for the import model. We also check the validity of the results obtained by estimating different country groups according to geographical or organizational clusters. Indeed, in the high-income countries (OECD countries), the NTB has a positive influence on the trade, while among the countries of the Gulf and Asian countries like India, the NTB influences trade between these countries. These results are different from a group to another. This provides evidence that trade policy affects Pakistan's trade with these major partners, but the degree of influence depends on the geographical location and the organization to which the trading partner belongs. In all cases, strict environmental policies and high costs of goods and services reduce trade flows between Pakistan and its partners. On the other hand, free trade policy is seen as an effective way to stimulate trade in the case of Pakistan. 


\subsection{Discussion and implications}

Today, in a world of competition, national policies are more protectionist. States prefer to protect themselves against increasingly unfair international competition, mainly in developing countries, by imposing taxes on international companies, thereby encouraging domestic production and imposing restrictive measures. These laws and measures are sometimes reinforced by a strict environmental policy, particularly in developed countries. The results of this study lead us to conclude that more stringent environmental policies reduce international competitiveness (Xu 2000). Strict environmental policies have a substantial impact on foreign trade, so reduce Pakistan trade flows.

The results found in Tables 3 and 4 regarding the variables of trade policies suggest that the signs of the coefficients are opposite in both models. In other words, when the coefficient is positive in one, it is negative in the other, and when it is significant in one, in the other, it is not. The results of this study on the impact of non-tariff barriers on Pakistan's trade flows are mixed. A positive influence of NTB for high-income countries reveals that high-income countries generally protect themselves against high-income countries. Also developing countries are protecting themselves more and more from each other, hence there is negative effect of the NTB on Pakistan's trade with the Gulf countries and Asian countries such as Bangladesh, Afghanistan. This brings back into question previous studies that claim that NTB affects trade flow negatively (Disdier et al. 2008).

In a global competition where barriers between countries are increasingly being created, nations are being led to open up more through the free trade agreement. Meanwhile, Pakistan has much effort to make its economy more attractive. As the results have shown, FTA was found to be positive and statistically significantly correlated with trade. However, as the new policy forecast, Pakistan should multiply trade agreements with major partners such as China to boost its economy.

Finally, we noted that Pakistan's major export is more focused on non-agricultural products. The new trade policy will be focused on addressing investment gaps to create an export surplus, gender mainstreaming and rationalization of tariffs besides suggesting measures to raise export of services to improve export competitiveness and diversify markets and products. Also, re-examine the terms of free trade agreements to obtain better market access for the country's products.

Pakistan aims to achieve the following targets: enhancement of annual exports to US\$ 35 billion; improve export competitiveness; the transition from factor-driven economy to efficiency-driven and innovation-driven economy; increase share in regional trade key enablers to achieve the above targets.

Acknowledgements

First, I thank the founder and Director of the Institute of transport and logistics and all members of the Institute of transport and logistics of Hunan University for their help, support, and sympathy.

\section{Authors' contributions}

$\mathrm{AY}$ is the main author of the manuscript; he undertook the literature review, developed the theoretical framework, collected and analyzed the data from the different sources. AD is a co-author of this manuscript; she approved the research idea, supported the empirical data analysis, gave suggestions and comments. Both authors read and approved the final manuscript. 


\section{Authors' information}

Alassane Yeo is a Ph.D. student at the School of Economics and Trade, member of the Institute of transport and logistics (http://www.tl-hnu.cn), Hunan University, Changsha, China, yadouni@yahoo.fr.

Aimin Deng, is a full-time professor and doctoral supervisor at the School of Economics and Trade, the founder and Director of the Institute of transport and logistics (http://www.tl-hnu.cn), Hunan University, Changsha, China, aimindeng@hnu.edu.cn.

Funding

This research was financially supported by the project of the National Social Science Fund of China (No. 18BJY168).

Availability of data and materials

The sources of bilateral trade flows (export and import) data are the World Integrated Trade Solution (WTIS). Data on GDP and population are obtained from World Bank Data. Variables related to bilateral distance, common language, common border from CEPII GeoDist database. FTA is collected from the WTO website. Data on environmental policy stringency and non-tariff barriers come from, respectively, OECD and WTS and then calculated based on Walter and Ugelow's (1979) Environmental Stringency Index, which measures countries environmental policy strictness and ranks countries from 1 (strict) to 7 (tolerant). The same calculations were done for NTB because of the lack of data on European countries

\section{Competing interests}

The authors declare that they have no competing interests.'

\section{Author details}

${ }^{1}$ School of Economics and Trade, Hunan University, Changsha 410082, China. ${ }^{2}$ Institute of Transportation and Logistics, Hunan University, Changsha 410082, China.

\section{Appendix 1}

\section{See Table 5.}

Table 5 Variable description

\begin{tabular}{|c|c|c|}
\hline Variable & Definition & Source \\
\hline EXP & Exports of goods and services (US) & $\begin{array}{l}\text { The World Integrated Trade Solution } \\
\text { (WITS) }\end{array}$ \\
\hline IMP & Imports of goods and services (US) & $\begin{array}{l}\text { The World Integrated Trade Solution } \\
\text { (WITS) }\end{array}$ \\
\hline GDP & $\begin{array}{l}\text { Gross domestic product in current } \\
\text { prices (USD) }\end{array}$ & $\begin{array}{l}\text { World Bank's World Development } \\
\text { Indicators (WDI) }\end{array}$ \\
\hline POP & Population & $\begin{array}{l}\text { World Bank's World Development } \\
\text { Indicators (WDI) }\end{array}$ \\
\hline DIST & Bilateral distance & CEPII GeoDist database \\
\hline NTB & Non-tariff barriers & $\begin{array}{l}\text { The World Integrated Trade Solution } \\
\text { (WITS) }\end{array}$ \\
\hline EPS & Environmental policy stringency & OECD website \\
\hline COST & Entry costs & The World Development Indicators \\
\hline FTA & $0=$ non-free trade agreement & WTO website \\
\hline (Dummy) & $1=$ free trade agreement & \\
\hline $\mathrm{CL}$ & $0=$ non-common language & CEPII GeoDist database \\
\hline (Dummy) & $1=$ common language & \\
\hline$C B$ & $0=$ non-common border & CEPII GeoDist database \\
\hline (Dummy) & $1=$ common border & \\
\hline
\end{tabular}




\section{Appendix 2: Environmental policy stringency measure}

The ESP measure used in this study is based on Walter and Ugelow (1979) who define 1 as strict and 7 as tolerant. We re-define it by setting $1=$ tolerant and $7=$ strict. The results are reported in Table 6 together with the sample composition.

Table 6 Environmental policy stringency measure

\begin{tabular}{|c|c|c|c|}
\hline ESP & Description & & Countries \\
\hline 1 & Tolerant & & Afghanistan, Bangladesh \\
\hline 2 & Tolerant to moderate & & Pakistan \\
\hline 3 & Moderate to tolerant & & United Arab Emirates, India, Saudi Arabia \\
\hline 4 & Moderate & & China, Italy, Spain \\
\hline 5 & Moderate to strict & & Belgium, United States \\
\hline 6 & Strict to moderate & & $\begin{array}{l}\text { The United Kingdom, Germany, France, } \\
\text { South Korea }\end{array}$ \\
\hline 7 & Strict & & Netherlands \\
\hline NTB & & Description & Countries \\
\hline 1 & & Tolerant & \\
\hline 2 & & Tolerant to moderate & Afghanistan, Saudi Arabia \\
\hline 3 & & Moderate to tolerant & Bangladesh \\
\hline 4 & & Moderate & China \\
\hline 5 & & Moderate to strict & $\begin{array}{l}\text { United Kingdom, Germany, Italy, } \\
\text { Spain, France, Netherlands, } \\
\text { Belgium, India, South Korea }\end{array}$ \\
\hline 6 & & Strict to moderate & United States \\
\hline 7 & & Strict & United Arab Emirates \\
\hline
\end{tabular}

\section{Appendix 3}

See Table 7.

Table 7 Stringency of environmental regulations in the sample countries

\begin{tabular}{llllll}
\hline Variable & Obs & Mean & Std. dev. & Min & Max \\
\hline InEXPij & 150 & 13.50289 & 0.7616232 & 12.0866 & 15.28417 \\
InIMPij & 150 & 13.45673 & 1.327816 & 10.93107 & 16.21513 \\
InGDPj & 150 & 27.6664 & 1.653013 & 22.67737 & 30.52808 \\
InPOPj & 150 & 18.05514 & 1.46879 & 15.47222 & 21.03897 \\
InGDPi & 150 & 25.99404 & 0.2125536 & 25.64517 & 26.32375 \\
InPOPi & 150 & 18.96552 & 0.0600547 & 18.87235 & 19.05927 \\
InDISTij & 150 & 8.417443 & 0.6280471 & 6.692049 & 9.414698 \\
InNTBj & 150 & 1.470678 & 0.3510512 & 0.6931472 & 1.94591 \\
InEPSi & 150 & 0.7219672 & 0.0383682 & 0.6931472 & 0.7884574 \\
InEPSj & 150 & 1.411522 & 0.3903195 & 0.6931472 & 1.94591 \\
InCOSTi & 150 & 2.785541 & 0.1417769 & 2.617396 & 3.12676 \\
InCOSTj & 150 & 1.717925 & 1.312437 & -2.302585 & 4.462454 \\
CB & 150 & 0.1333333 & 0.3410734 & 0 & 1 \\
CL & 150 & 0.1333333 & 0.3410734 & 0 & 1 \\
FTA & 150 & 0.0533333 & 0.2254501 & 0 & 1 \\
\hline
\end{tabular}




\section{Appendix 4}

See Table 8.

Table 8 Regression results, robustness checks; dependent variable: InEXPij

\begin{tabular}{lllll}
\hline Variables & OECD & SAFTA & APEC & GCC \\
\hline InNTBj & $8.424^{* * *}$ & $4.711^{* * *}$ & $-5.136^{* * *}$ & $1.205^{* * *}$ \\
& $(0.872)$ & $(1.011)$ & $(0.641)$ & $(0.0908)$ \\
InEPSi & 1.079 & -0.685 & 2.014 & 1.605 \\
& $(1.300)$ & $(1.392)$ & $(1.531)$ & $(1.632)$ \\
InEPSj & $-0.668^{* *}$ & $-3.748^{* * *}$ & $7.730^{* * *}$ & - \\
& $(0.269)$ & $(0.803)$ & $(1.431)$ & 0.639 \\
InCOSTi & -0.130 & 0.0952 & 0.342 & $(0.494)$ \\
& $(0.353)$ & $(0.398)$ & $(0.439)$ & $-0.222^{* *}$ \\
InCOSTj & $-0.203^{* * *}$ & $-0.389^{* * *}$ & $-0.405^{* * *}$ & $(0.0985)$ \\
& $(0.0425)$ & $(0.106)$ & $(0.0954)$ & - \\
FTA & - & $0.614^{* *}$ & - & $9.643^{* * *}$ \\
& & $(0.245)$ & & $(2.153)$ \\
Constant & 0.698 & $12.96^{* * *}$ & $11.45^{* * *}$ & YES \\
Country FE & $(2.259)$ & $(2.277)$ & $(2.163)$ & 20 \\
Observations & YES & YES & YES & 0.923 \\
R-squared & 90 & 30 & 30 & \\
\hline
\end{tabular}

\section{Appendix 5}

See Table 9.

Table 9 Regression results, robustness checks; dependent variable: InIMPij

\begin{tabular}{lllll}
\hline Variables & OECD & SAFTA & APEC & GCC \\
\hline InNTBj & $8.724^{* * *}$ & $-2.468^{* * *}$ & $-4.619^{* * *}$ & 0.201 \\
& $(1.192)$ & $(0.465)$ & $(0.812)$ & $(0.122)$ \\
InEPSi & 0.330 & 0.875 & 1.678 & 1.228 \\
& $(1.776)$ & $(0.641)$ & $(1.938)$ & $(2.185)$ \\
InEPSj & $1.451^{* * *}$ & $-2.116^{* * *}$ & $15.96^{* * *}$ & - \\
& $(0.368)$ & $(0.370)$ & $(1.812)$ & \\
InCOSTi & -0.123 & -0.0939 & -0.215 & -0.244 \\
& $(0.482)$ & $(0.183)$ & $(0.556)$ & $(0.662)$ \\
InCOSTj & 0.0238 & $-0.379^{* * *}$ & $-0.390^{* * *}$ & -0.0211 \\
& $(0.0581)$ & $(0.0487)$ & $(0.121)$ & $(0.132)$ \\
FTA & - & 0.114 & - & - \\
& & $(0.113)$ & & $14.89^{* * *}$ \\
Constant & -3.437 & $21.89^{* * *}$ & $4.893^{*}$ & $(2.884)$ \\
& $(3.087)$ & $(1.048)$ & $(2.738)$ & YES \\
Country FE & YES & YES & YES & 20 \\
Observations & 90 & 30 & 30 & 0.214 \\
R-squared & 0.469 & 0.986 & 0.952 & \\
\hline
\end{tabular}


References

Arkolakis C (2010) Market penetration costs and the new consumers margin in international trade. J Pol Econ 118(6):1151-1199

Baldwin RE (1970) Nontariff distortions of international trade

Baysan T. (1992) Trade policies in Pakistan. In: National Trade Policies. pp 459-478

Beghin JC, Maertens M, Swinnen J (2015) Nontariff measures and standards in trade and global value chains. Annu Rev Resour Econ 7(1):425-450

Bergsten CF (1996) Globalizing free trade. Foreign Affairs 1:105-120

Bergstrand JH (1985) The gravity equation in international trade: some microeconomic foundations and empirical evidence. Rev Econ Stat 1:474-481

Campi M, Dueñas M (2019) Intellectual property rights, trade agreements, and international trade. Res Policy 48(3):531-545

Carrère C, De Melo J (2011) Notes on detecting the effects of non-tariff measures. J Econ Integr 1:136-168

Deardorff, A., \& Stern, R. M (1997) Measurement of Nontariff Barriers

Disdier A-C, Marette S (2010) The combination of gravity and welfare approaches for evaluating non-tariff measures. Am J Agric Econ 92(3):713-726

Disdier AC, Fontagné L, Mimouni M (2008) The impact of regulations on agricultural trade: evidence from the SPS and TBT agreements. Am J Agric Econ 90(2):336-350

Egger PH, Lassmann A (2012) The language effect in international trade: a meta-analysis. Econ Lett 116(2):221-224 Genç M, Law D (2014) A gravity model of barriers to trade in New Zealand. The Treasury, Wellington

Gerhardt T (2011) America's Pacific Century?: In: APEC summit in Hawaii seeks to implement free trade agreement of the Asia Pacific region. Common dreams

Ghodsi M, Stehrer R (2016) Non-tariff measures trickling through global value chains. In: Productivity, non-tariff measures and openness (PRONTO) working paper, Vienna Institute for International Economic Studies, Vienna

Grossman GM, Helpman E (1993a) The politics of free trade agreements (No. w4597). National Bureau of Economic Research, Cambridge

Grossman GM, Krueger AB (1993b) Environmental impacts of the North American FreeTrade agreement. The US-Mexico Free Trade Agreement, Buenos Aires

Haveman JD, Shatz HJ (2004a) Developed country trade barriers and the least developed countries: the current situation. J Econ Integr 19:230-270

Haveman JD, Shatz HJ (2004b) Developed country trade barriers and the least developed countries: the current situation J Econ Integr 19(2):230-270

Hummels D, Klenow PJ (2005) The variety and quality of a nation's exports. Am Econ Rev 95(3):704-723

Kawai M, Urata S (2012) Changing commercial policy in Japan, 1985-2010. The Oxford Handbook of International Commercial Policy. Oxford University Press, New York, pp 225-251

Kee HL, Nicita A, Olarreaga M (2009) Estimating trade restrictiveness indices. Econ J 119(534):172-199

Khouilid M, Echaoui A (2017) The impact of Non-Tariff Measures (NTMs) on Moroccan foreign trade: comparison between developed and developing countries. IOSR J Econ Fin 8(3):48-57

Klimenko M, Ramey G, Watson J (2008) Recurrent trade agreements and the value of external enforcement. J Int Econ 74(2):475-499

KoźlukT, Timiliotis C (2016) Do environmental policies affect global value chains?: A new perspective on the pollution haven hypothesis. OECD Publishing, Paris

Lan J, Munro A, Liu Z (2017) Environmental regulatory stringency and the market for abatement goods and services in China. Resour Energy Econ 50:105-123

Lee JW, Swagel P (2017) Trade barriers and trade flows across countries and industries. Rev Econ Stat 79(3):372-382

Levitt CJ, Saaby M, Sørensen A (2019) The impact of China's trade liberalisation on the greenhouse gas emissions of WTO countries. China Econ Rev 54:113-134

Lewis SR Jr, Guisinger SE (1968) Measuring protection in a developing country: the case of Pakistan. J Polit Econ 76(6):1170-1198

Lincoln WF, McCallum AH (2016) Entry Costs and Increasing Trade. In: US Census Bureau Center for Economic Studies Paper No. CES-WP-11-38R

Linnemann H (1966) An econometric study of international trade flows. NorthHolland, Amsterdam

Nicita A, Gourdon J (2013) A preliminary analysis on newly collected data on non-tariff measures. In: United Nations Conference on Trade and Development

OECD (2017). http://www.oecd.org/unitedstates/publicationsdocuments/reports/

Okabe M (2015) Impact of free trade agreements on trade in East Asia. In: ERIA Discussion Paper Series. 1(48)

Pöyhönen Pentti (1963) Toward a general theory of the international trade. Economiska Samfundets Tidskrift 16:69-77

Pulliainen K (1963) A world trade study: an econometric model of the pattern of the commodity flows of international trade in 1948-60. Economiska Samfundets Tidskrift 16:78-91

Qi C, Zhang JX (2018) The economic impacts of the China-Australia Free Trade Agreement-A general equilibrium analysis. China Econ Rev 47:1-11

Rotunno L (2016) Political stability and trade agreements: evidence for 'endgame FTAs'. Eur J Polit Econ 45:133-148

Shujiro U, Misa O (2007) The impacts of free trade agreements on trade flows: an application of the gravity model approach (07052)

Steingress W (2015) The causal impact of migration on us trade: evidence from a natural experiment

Tinbergen Jan (1962) Shaping the World Economy: Suggestions for an International Economic Policy. The Twentieth Century Fund, New York

Urata S, Kiyota K (2003) The impacts of an East Asia FTA on foreign trade in East Asia. National Bureau of Economic Research (w10173) 
Van Beers C, Van Den Bergh JC (1997) An empirical multi-country analysis of the impact of environmental regulations on foreign trade flows. Kyklos 50(1):29-46

Van Tongeren F, Beghin J, Marette S (2009) A cost-benefit framework for the assessment of non-tariffmeasures in agrofood trade

Walter H (1973) Vegetation of the earth in relation to climate and the eco-physiological conditions. English Universities Press, London

Walter I, Ugelow JL (1979) Environmental policies in developing countries. Ambio pp 102-109

Xu X (2000) International trade and environmental regulation: time series evidence and cross section test. Environ Resour Econ 17(3):233-257

\section{Publisher's Note}

Springer Nature remains neutral with regard to jurisdictional claims in published maps and institutional affiliations.

Submit your manuscript to a SpringerOpen ${ }^{\circ}$ journal and benefit from:

- Convenient online submission

- Rigorous peer review

- Open access: articles freely available online

High visibility within the field

- Retaining the copyright to your article

Submit your next manuscript at $\boldsymbol{\nabla}$ springeropen.com 